\title{
THE ROLE OF COMMERCIAL RADIO STATIONS IN THE MEDIA VACUUM OF MAI 68 IN PARIS
}

\author{
Richard Legay \\ $\mathrm{C}^{2} \mathrm{DH}$ \\ Luxembourg Centre for Contemporary and Digital History \\ Université du Luxembourg \\ Maison des Sciences Humaines \\ 11, Porte des Sciences \\ L - 4366 Esch-Belval \\ Luxembourg \\ richard.legay@uni.lu
}

\begin{abstract}
Commercial radio stations RTL and Europe $\mathrm{n}^{\circ} 1$ played an important role during the events of May 1968 in Paris by maintaining the news coverage of the protests, the riots and the strikes. By analyzing the entanglements of the various audiovisual media and surviving audio material, this article defends the idea that a vacuum created by the crisis that affected the French public broadcasting agency is one of the main reasons that brought the commercial radio stations to the centre of the events.
\end{abstract}

Keywords: radio, France, entanglements, ORTF, RTL, Europe 1.

The media played a crucial role in the understanding of the events of Mai 68 in Paris, as the video footage and numerous photographs available to historians revealed. These great testimonies were tremendous sources for researchers. In France however, it was the commercial radio stations that were at the centre of attention during the events, ${ }^{1}$ as they were the main source of information through their live news coverage of Mai 68 . The radio stations RTL (Radio-Télévision-Luxembourg) and Europe $n^{\circ} 1$ were listened to by many throughout the entire month and were even nicknamed "radio barricades" by Prime Minister Georges Pompidou. ${ }^{2}$ Through this live coverage of events, the commercial radio stations informed listeners of what was happening and where; they retransmitted important speeches and gave a voice to crucial actors. They had a direct influence on the events, and they were more than just witnesses. ${ }^{3}$

The question of this article will not be to understand the impact of RTL and Europe $n^{\prime} 1$ during Mai 68, but rather to analyse why they were such prominent actors during the events. The explanation relies on three points. First, the commercial radio stations were part of a bigger audiovisual media system, in which public and commercial radio

1 Jacques Capdevielle and Henri Rey, eds., Dictionnaire de Mai 68, Larousse, 2008, pp. 417-418.

2 Jean-Jacques Cheval, "Mai 68, un entre-deux dans l'histoire des médias et de la radio en France", Website of the Groupe d'Etudes et de Recherche sur la Radio, January 2009.

3 Hervé Glévarec, “Le reportage radiophonique des << événements >>: Mai 68 a-t-il inventé << l'effet de réel >> en radio ?", in Christian Delporte, Denis Maréchal, Caroline Moine and Isabelle Veyrat-Masson, eds., Images et sons de Mai 68 (1968-2008), Nouveau Monde Éditions, 2011, p. 36. 
stations were strongly entangled with one another and with television. The role of one audiovisual medium could only be understood in relation to the other ones, through the concept of entanglements in media history. ${ }^{4}$ The second point of explanation could be found in the creation of a media vacuum during Mai 68, partly because of the criticisms against the French television and the national public broadcasting agency (the ORTF, the Office de RadiodiffusionTélévision Française) that led to strikes that reduced the public stations to almost complete silence. It was in reaction to this vacuum that commercial radio stations played such a crucial role during the events. One additional point is the details of the live broadcasts from that time that contained strong visual impressions, an element that helped to compensate the void left by other audiovisual media during Mai 68. Four of these recordings have been embedded in this article and will be analysed in order to engage the readers, and listeners, in the understanding of these broadcasts.

\section{A System of Entangled Media}

The audiovisual landscape in France in 1968 was divided between the public service, the ORTF, and the private, commercial radio stations, called radios périphériques, whose transmitters were based outside the French territory. However, only two of these stations were of interest for this article: Europe $n^{\circ} 1$ (whose transmitter was based in Saarland, Germany) and RTL (formerly Radio Luxembourg, whose transmitter was based in the Grand Duchy of Luxembourg). These were the most listened-to radio stations alongside France Inter, which was part of the ORTF. The latter was the name given to the national agency providing France with public radio and television broadcasting, under strict governmental supervision from the Ministère de l'Information, ${ }^{5}$ especially with regard to news coverage and information programs. ${ }^{6}$ This agency was interesting in showing the entanglements ${ }^{7}$, the points of interconnectedness, between the various media in the French case. The commercial radio stations also shared similarities, especially because they both relied on advertisements as their main source of revenue ${ }^{8}$ and targeted a similar 'youth' audience, leading to fierce competition between $R T L$ and Europe $n^{\circ} 1$. Despite having their transmitters outside of France, the commercial radio stations targeted the French audience, competing against each other and against ORTFs programmes. This transnational position, with offices in Paris and transmitters in other countries, also included entanglements through political boundaries as RTL staff in Paris were pressured by the French government not to support the protesters; otherwise, the lines connecting the office to Luxembourg would be cut $^{9}$. These examples revealed some of the connections, in terms of audience, borders and political power, operating in this system of entangled media.

Although television was a growing medium in France at the time, it was not as developed in 1968 as it was in the United Kingdom, partly because it was seen by the French government as an extension of radio. ${ }^{10}$ This reinforced the idea of French public broadcasting being a whole, singular entity, an idea that was also supported by the fact that

4 Marie Cronqvist and Christoph Hilgert, "Entangled Media Histories: The value of Transnational and Transmedial Approaches in Media Historiography", Media History, 23, 1, 2017, pp. 130-141.

5 Jean-Noël Jeanneney, Une Histoire des médias. Des origines à nos jours, Seuil, 2011, p. 310.

6 Jean-Pierre Filiu, Mai 68 à l'ORTF. Une radio-télévision en résistance, Nouveau Monde Éditions, 2008 , p. 38.

7 Marie Cronqvist and Christoph Hilgert, "Entangled Media Histories: The Value of Transnational and Transmedial Approaches in Media Historiography", Media History, 23, 1, 2017, pp. 130-141.

8 Denis Maréchal, "Entre monopole des radios publiques et postes périphériques", in Hervé Glévarec, ed., Histoire de la radio: ouvrez grand vos oreilles!, Catalogue de l'exposition au Musée des Arts et Métiers, Silvana Editoriale, 2012, p. 51.

9 Interview between the author and Jean-Pierre Farkas, Paris, 17th February 2015.

10 Jean-Noël Jeanneney, Une Histoire des médias. Des origines à nos jours, Seuil, 2011, p. 295. 
the Minister for Information was the head of public broadcasting. ${ }^{11}$ Alain Peyrefitte, who occupied this position between 1962 and 1966, even explained that in 1962, De Gaulle said, "television was his"12 medium, in contrast to a press he saw as an adversary. Television sets did, however, become more and more common in France during the Sixties. According to the numbers quoted by Aude Vassallo, 7\% of French homes owned a set in 1958; this number reached $62 \%$ in $1968 .{ }^{13}$. The journal télévisé, the news bulletin, was watched by $92 \%$ of viewers in $1968 .{ }^{14}$ A second television channel started broadcasting at the end of 1963, and colour was introduced in 1967.

Radio was also a popular medium in France; $91.3 \%$ of French people owned at least one radio set in $1968 .{ }^{15}$ In 1967 , $53.6 \%$ of the population said they listened to the radio every day, revealing how strongly integrated into everyday lives the medium was. Surveys in 1967 put France Inter in a strong leading position in terms of the size of its audience, followed by Europe $n^{\circ} 1$ and $R T L$ as a close third. French listeners were limited to stations run with a strong influence from the state.

The rise in popularity of television did not mean people stopped listening to the radio; the two media co-existed in the French population's habits. Television viewers were also radio listeners, and those who favoured one station over another were not necessarily exclusive. The ORTF consisted of radio and television and their programmes followed similar guidelines, while the commercial radio stations each tried to appeal a younger audience, sharing codes, tones and tastes, to compete with one another. These elements reflect the connections that existed between the different actors of an entangled media system.

\section{The Vacuum Left Behind by Television and the Public Broadcasting Service}

The ORTF faced an internal crisis during the months of May and June 1968. This led to a massive strike from May 17 th to 23rd June, in which around 12000 people from various services within the public broadcasting agency participated. ${ }^{16}$ The roots of the crisis can be traced to internal criticism prompted by the agency's decision to introduce advertisements on public channels as a new stream of revenue in April 1968. ${ }^{17}$ However, it was the events of Mai 68 that triggered the beginning of the crisis. More precisely, the government's ban on the magazine Panorama is commonly accepted as the starting point of the strike, ${ }^{18}$ which spread quickly through the different services, leaving only a handful of staff members who did not take part. Some television journalists published a press release detailing their motives in the early days of the strike. In the press release, they criticized "an outrageous failure of providing viewers with information"19 that corroborated the lack of images and limited information from television in the first days of the Mai 68 events. Following the declaration of the strike, only the minimum service was maintained on both public radio and television, rendering them almost completely silent.

\footnotetext{
11 Jean-Noël Jeanneney, Une Histoire des médias. Des origines à nos jours, Seuil, 2011, p. 310.

12 Alain Peyrefitte, C'était de Gaulle, Gallimard, 2002, p. 500.

13 Aude Vassallo, La Télévision sous de Gaulle. Le Contrôle gouvernemental de l'information (1958/1969), De Boeck, 2005, p. 13.

14 Aude Vassallo, La Télévision sous de Gaulle. Le Contrôle gouvernemental de l'information (1958/1969), De Boeck, 2005, p. 193.

15 Pierre Miquel, Histoire de la radio et de la télévision, Perrin, 1991, p. 203.

16 Jean-Pierre Filiu, Mai 68 à l'ORTF. Une radio-télévision en résistance, Nouveau Monde Éditions, 2008, p. 67.

17 André-Jean Tudesq, “Le conseil d'administration de l'ORTF et la crise de 1968”, Groupe d'Etudes et de Recherches sur la Radio, 2009

18 Jacques Capdevielle and Henri Rey, eds., Dictionnaire de Mai 68, Larousse, 2008, p. 313.

19 Marie-Françoise Lévy \& Michelle Zancarini-Fournel, "La genèse d'un conflit: mai 68 à l'ORTF”, transcription of a seminar organised at the Institut du Temps Présent, Paris, 12th February 1996.
} 


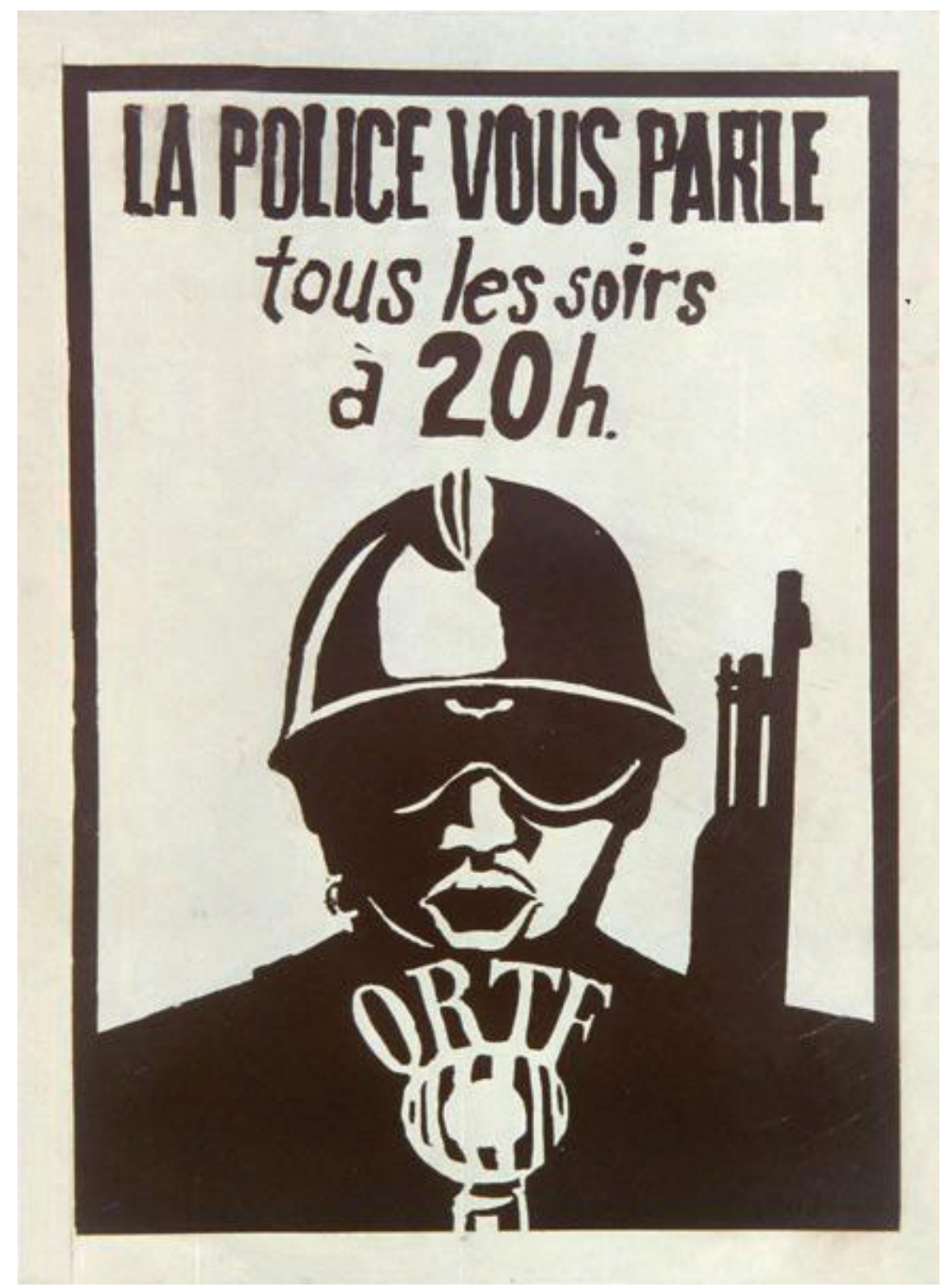

Figure 1. ORTF : La police vous parle tous les soirs à 20h, BnF, Département des Estampes et de la photographie, ENT QB-(1968)/W3890.

The poster made during the events of Mai 68 (see Figure 1) is an interesting reflection of the way the ORTF was seen: it was an extension of the government's authority, a factor undermining the trust people put in ORTF's coverage of the events. "The police are talking to you every evening at 8 pm" was a slogan criticising the authoritarian aspects of the Gaullist government, especially its control over the media; it also revealed the disdain and criticism expressed by some against both television and radio functioning under the same institutional umbrella, the ORTF. It is interesting to notice the alignment of two different media - pictured as ORTF - as merely a simple relay of the government's voice. This voice, embodied in the character of the policeman, is a powerful criticism of an authoritarian regime that, turned the broadcasting agency into a propaganda tool, in which radio and television are blended in the eyes of their detractors.

The poster pictured in Figure 2, on the other hand, displays an interesting representation of the thirst for independence coming from staff members of the ORTF, who appear to be willing to leave the government grip symbolized by barbed wire. It is worth noticing that this second poster associates the ORTF with a television screen while the first one 


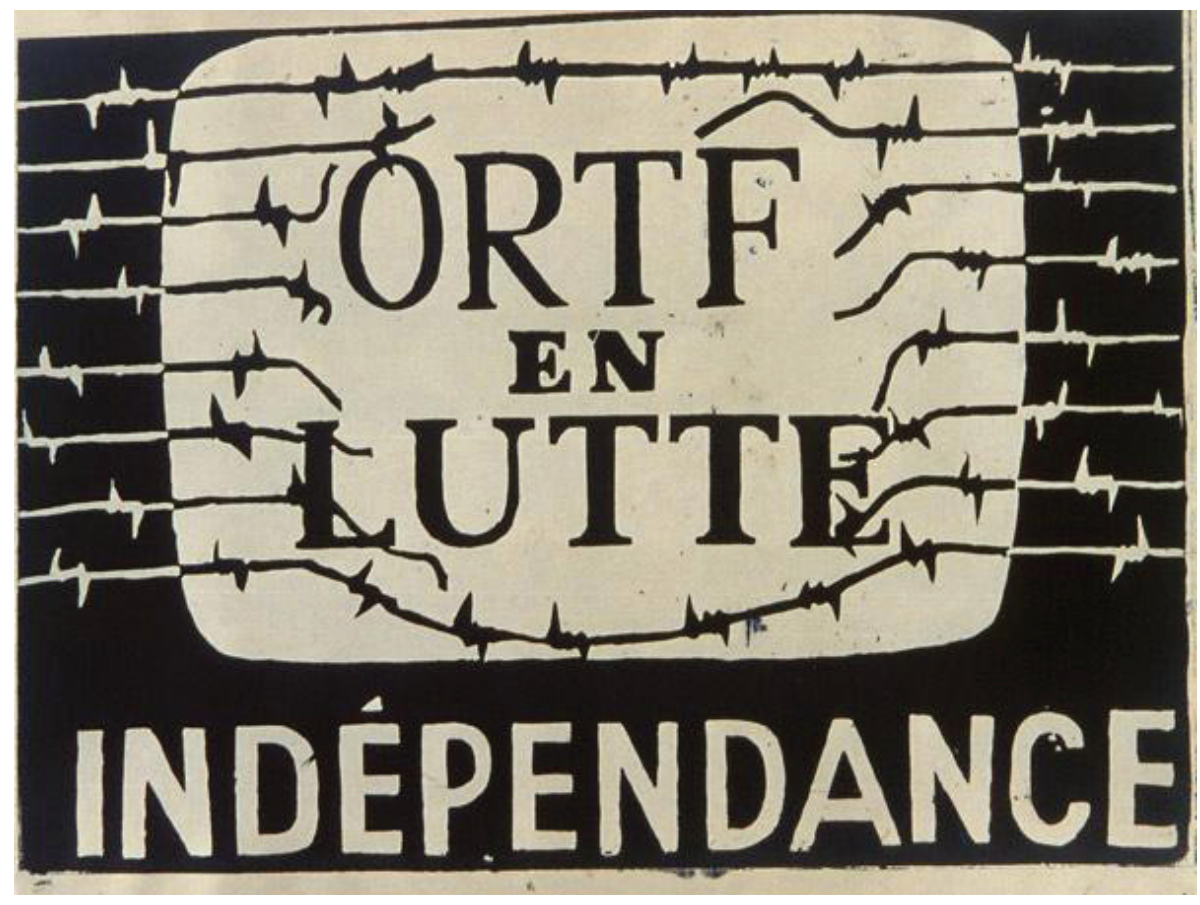

Figure 2. ORTF en lutte. Indépendance., BnF, Département des Estampes et de la photographie, ENT QB-(1968)/W3771

associates it with a microphone, indicating once more the fluidity and entanglement between audio and visual representations of the broadcasting agency. The two posters show the complexity of feelings towards the ORTF that was often criticised - both internally and externally - for its submission to the government's authority.

The governmental control, the mistrust by some parts of the population, and the minimum service provided due to the strikes all created a vacuum of information in the audiovisual media landscape. It is in reaction to this vacuum that commercial radio stations filled in the gap in the news coverage of the events.

People clustered around transistor radios in Paris to listen to live news coverage ${ }^{20}$ from radio stations covering demonstrations, speeches and protests. Testimonies from reporters ${ }^{21}$ and protesters described the way people who did not necessarily know each other gathered around a portable transistor radio to listen to the news, react to it and share comments. These practices remind one of radio's ability to facilitate 'co-presence', ${ }^{22}$ meaning that an individual listening to a radio station is also part of a broader community of listeners. In the context of Mai 68 , this community became even more tangible as people gathered around radios and exchanged opinions about what was being broadcast. The strikes of the ORTF staff disrupted the ways people listened to radio stations at the time, while the silence of public services helped grow the listening community of the commercial radio stations.

The transistor radio appears as a key to understand the central role played by radio stations during the events of Mai 68, and it is interesting to notice that it was described by the press as the "umbilical cord that connects France to its revolution". ${ }^{23}$ An RTL reporter considered that it was, with the Nagra recorder, one of the main objects of 
Mai 68 when it came to information. ${ }^{24}$ According to the figures quoted by Sirinelli and Rioux, around two-thirds of French people listened to radio stations through a transistor radio in $1968,{ }^{25}$ meaning that the main object of listening at the time was one characterised by its mobility, as it was a light and transportable object, functioning on a battery. The transistor, and by extension radio, became synonymous with information ${ }^{26}$ during Mai 68 , reinforcing the idea that information was a key issue for audiovisual media, especially for commercial radio stations. Jean-Pierre Farkas, editor-in-chief at RTL during the events of Mai 68, explained the way he and his team felt obliged to provide information to listeners, particularly when other media were not able to fulfil this responsibility. According to him, they were using live coverage more often during these events than in the previous years. ${ }^{27}$ This vacuum of information left by public television channels and radio stations could be filled by $R T L$ and Europe $n^{\circ} 1$ as they could rely on mobility: the Nagra recorder allowed reporters to collect information on the streets, outside of a studio, and the transistor radio allowed listeners to hear information on the streets, in groups of people who were not family.

Instead of the multiple sources of radio and television information from an entangled audiovisual system, the vacuum created by the public service strike led to reduced options for the French audience, meaning that their focus shifted towards the two commercial stations instead of the previous balance between the commercial and state-managed stations.

\section{Highly Visual Audio Documents}

To better understand the specifics of how commercial radio stations affected the events of Mai 68 , it is valuable to investigate some audio documents that are available. Analysing them on a closer level allows a better understanding of news coverage. Four audio documents were chosen as examples (see Audio 1, 2, 3 \& 4). It is not known how many hours of footage were preserved, but only a limited quantity is accessible.

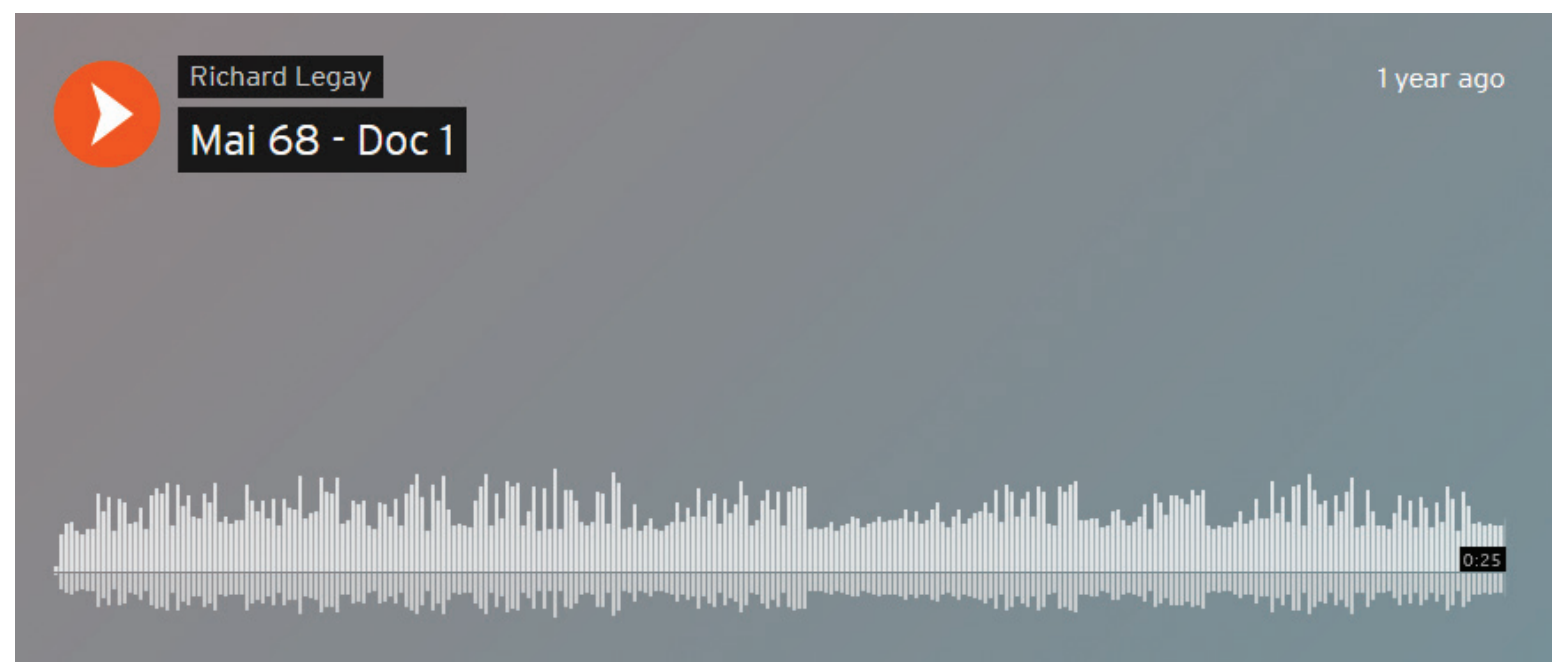

Audio 1. "First fights on the Boulevard St-Michel", RTL, 3rd May 1968, Paris ${ }^{28}$. Go to the online version of this article to play the audio.

24 Interview between the author and Christian Brincourt, Paris, 10th March 2015.

25 Jean-Pierre Rioux and Jean-François Sirinelli, La Culture de masse en France de la Belle époque à aujourd'hui, Fayard, 2001, p.127.

26 Elvina Fesneau, Le Poste à transistors à la conquête de la France. La radio nomade (1954-1970), INA Editions, 2011 , p. 300.

27 Interview between the author and Jean-Pierre Farkas, Paris, 17th February 2015.

28 extract from RTL, Les Journées de Mai 68 par les journalistes de RTL, Philips, 1968, documents presented by Jean-Pierre Farkas. 


\section{Mai 68 - Doc 2}

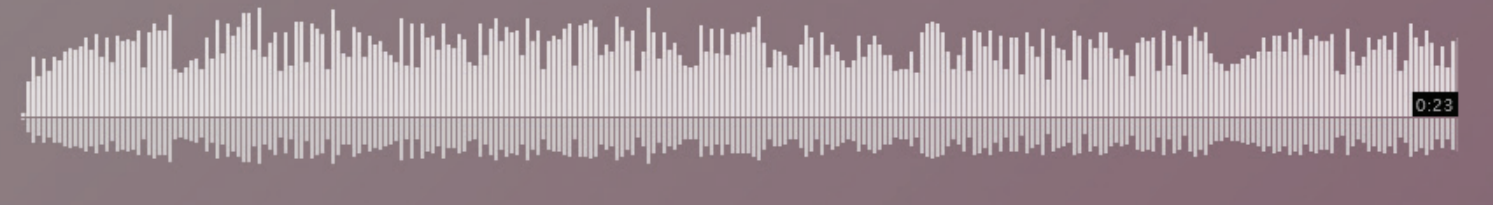

Audio 2. "First riots in the Quartier Latin", RTL, 6th May 1968, Paris ${ }^{29}$. Go to the online version of this article to play the audio.

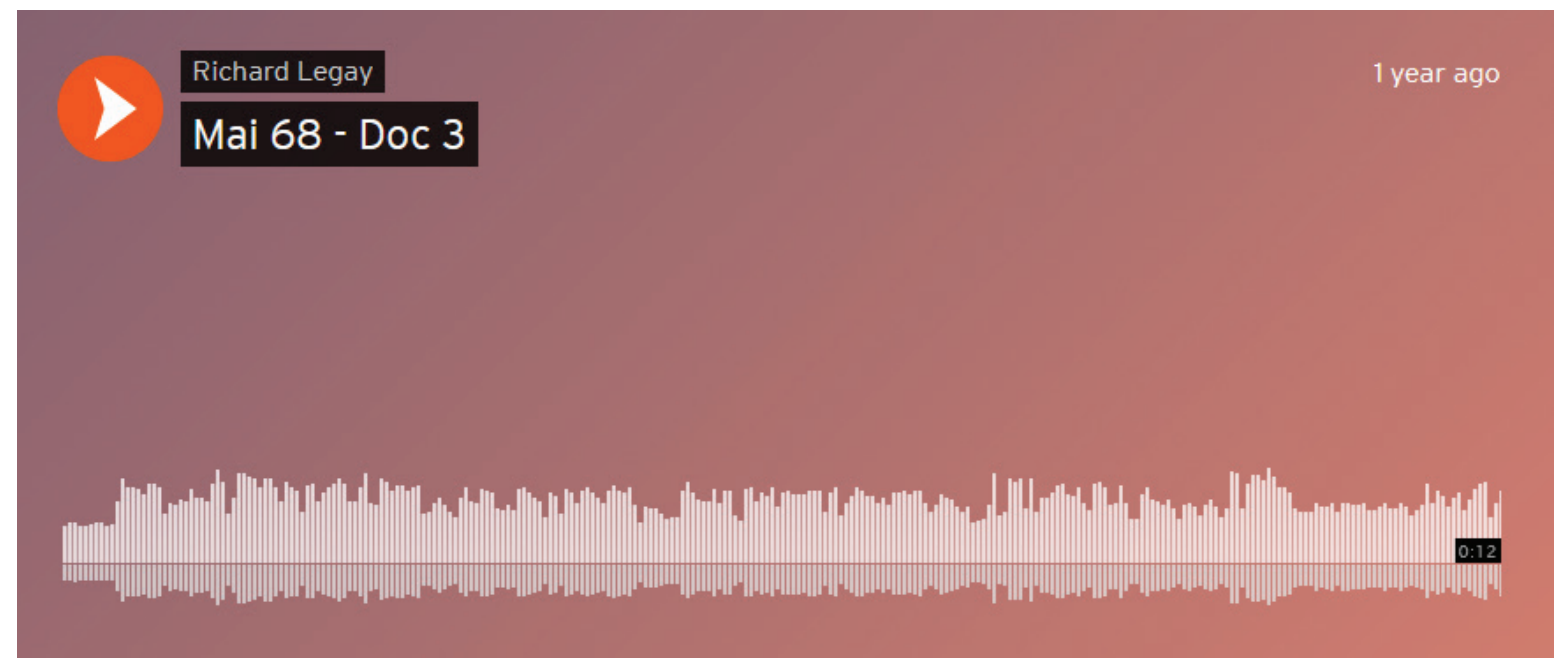

Audio 3. "Woman covered in blood in the Quartier Latin", RTL, 6th May 1968, Paris ${ }^{30}$. Go to the online version of this article to play the audio.

29 extract from RTL, Les Journées de Mai 68 par les journalistes de RTL, Philips, 1968, documents presented by Jean-Pierre Farkas.

30 extract from RTL, Les Journées de Mai 68 par les journalistes de RTL, Philips, 1968, documents presented by Jean-Pierre Farkas. 


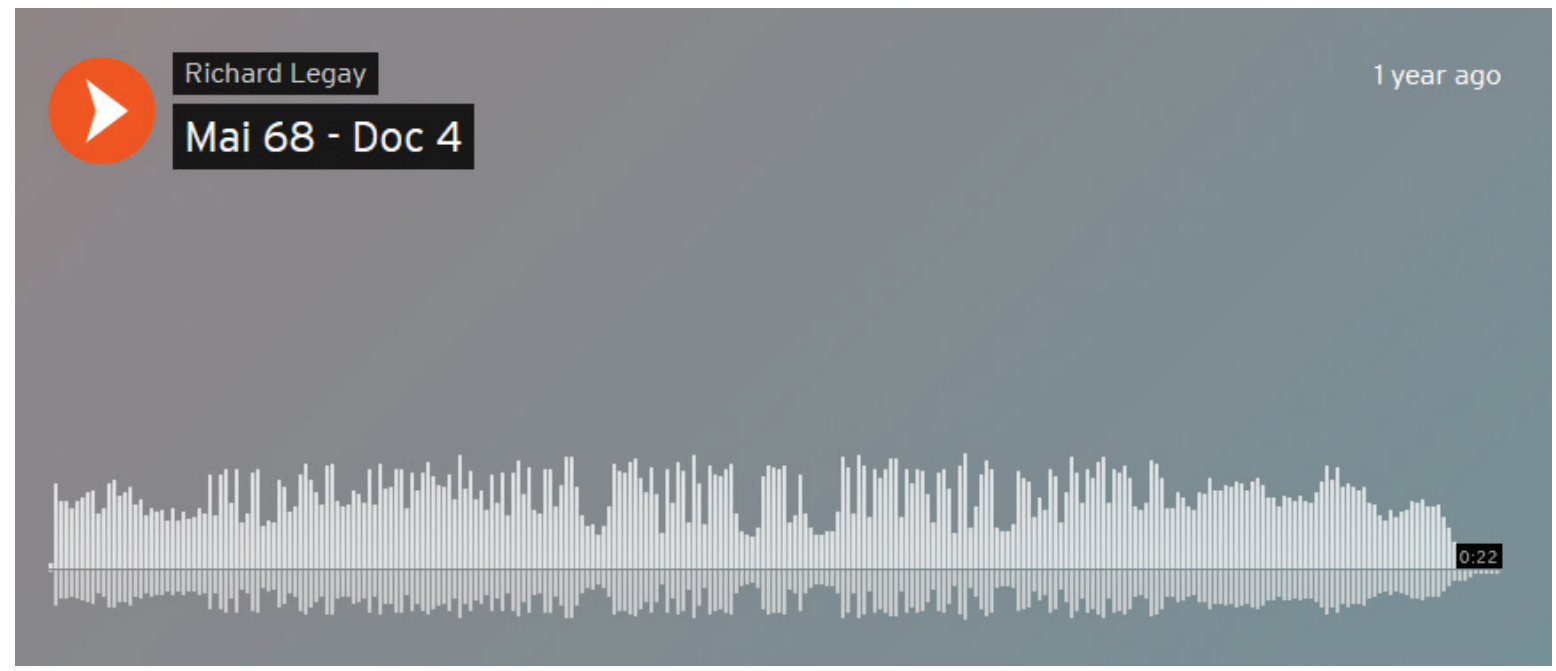

Audio 4. "Gilles Schneider covering the protests on the Boulevard St-Germain", Europe ${ }^{\circ} 1,6$ th May 1968, Paris ${ }^{31}$. Go to the online version of this article to play the audio.

The audio documents were chosen for various reasons, including their sonic quality, as well as content that is accessible to non-French-speaking listeners. This means that the documents are not representative of the coverage of the events by the commercial radio stations, nor of what was usually broadcasted during Mai 68. They illustrate turning points of the events during which the radio stations played a significant role in informing and testifying, which justify their analysis in this article. Other radio programmes were broadcast and listened to during the events, such as interviews and advertisements. The documents chosen are characterised by a strong presence of violence, and they are all from the early events of May 1968. The first three documents were published soon after the events by RTL on a vinyl, and the station used selected excerpts from their own recordings of the radio coverage presented by JeanPierre Farkas. This commercial publication could indicate that RTL quickly realised the value of its footage. It is not known how many records were sold. The fourth document is from Europe $n^{\circ} 1$; it is part of French historian Hervé Glévarec's personal archives, who kindly provided the author access to it.

Various elements present in these documents constructed the visuality of these audio recordings. First of all, the narration was crucial in shaping visual impressions; so are the emotions in the reporters' voices and the various background noises that were well captured in the documents. All these features had an impact on the listeners as they created an 'effect of reality', causing them to believe in the authenticity ${ }^{32}$ of the live coverage and engage with it in a different way during Mai 68, a time of crisis.

\subsection{Visuality through Narration}

Speech is considered the primary code of radio, ${ }^{33}$, which makes it a central element in the analysis of the documents. Narration played a crucial role in reporting stories, and the use of descriptions is a norm, especially in the coverage of

31 extract from the personal archives of Hervé Glévarec, CNRS.

32 Hervé Glévarec, “Le reportage radiophonique des << événements >>: Mai 68 a-t-il inventé $<<$ l'effet de réel >> en radio ?", in Christian Delporte, Denis Maréchal, Caroline Moine and Isabelle Veyrat-Masson, eds., Images et sons de Mai 68 (1968-2008), Nouveau Monde Éditions, 2011, p. 35.

33 Andrew Crisell, Understanding Radio, second edition, Routledge, 1994, p. 3. 
the Mai 68 events. The live descriptive narrations were essential to conjuring a visual imagination in the radio format despite the absence of images. This is present in the documents when reporters mention cars, protesters, police forces and the various movements they see. While these elements are worth mentioning, they are not particularly different from other radio coverage at the time.

There is another level of comprehension when analyzing how these audio documents break the customary journalistic norms of narration. This is the case of the first document, in which the reporter was interrupted by a second male voice which told him to watch out for a cobblestone: "Attention, attention François, il y a un pavé" [around 0:09]. This extradiegetic interruption did not break the intimacy created with listeners through liveness. ${ }^{34}$ On the contrary, it reinforced the feeling of connection as listeners heard this remark at the same time the reporter did. This directly echoed the words of the reporter in the second document, in which he was hurt and expressed his pain, before asking someone to move: "Oh, ouille, aïe, la vache, pousse-toi" [around 0:11]. Here again, the comments reinforced the 'effect of reality' expressed by Hervé Glévarec ${ }^{35}$ and also create a feeling of sympathy for the reporter who was clearly hurt in the process. These two moments disrupted the narration but also enhanced its authenticity. The concept of liveness is a core feature of both radio and television. ${ }^{36}$ It applies well to radio, especially during Mai 68 , when so much was expected of the reporters. This liveness questioned and blurred the limits of extra- and intradiegetic elements in these audio documents, as many non-verbal elements were not part of the narration conducted by the reporter but still concurred to create a strong visual impact.

\subsection{Visuality through Emotions}

In these recordings, it was possible to hear emotions through the voices of reporters who were facing a potentially dangerous situation. The second document illustrates this the best, as one could hear numerous hesitations and repetitions of words and some stuttering. The various voices heard in the documents conveyed a broad range of emotions, including stress, pain, and fear, something different from what was usually heard in news segments narrated by seasoned journalists. An explanation given by Jean-Pierre Farkas ${ }^{37}$ is that many reporters sent to cover the protests had experience in commenting on sports, a format that differed from more traditional news reports as it could be quicker and more emotional.

In the third document, the reporter described a woman who appeared to be lying on the ground, covered in blood, before he was interrupted by students charging in his direction. This description seemed tainted by emotion as one could hear the reporter repeating himself and stuttering at one point. His first words explaining that he was in Boulevard Saint-Germain sounded like screaming meant to cover the background sounds, which gave a more dramatic atmosphere to the entire recording. If descriptions can create one layer of visual elements, the emotions that coloured the speech added another dimension as they affected listeners in a powerful manner and modulated the representations of the scene described. The description of the woman covered in blood, lying on the ground, was quick and simple, but when the emotion in the reporter's voice was taken into account, the scene became more visual, intense, and suggestive of the surrounding violence. On the other hand, in the fourth document, the reporter sounded rather calm, despite the violent noises heard in the background. However, he did repeat himself on a few occasions. This impacted the narration differently, creating a sentiment of relative incomprehension and chaos, a characteristic of the live radio coverage during Mai 68. 


\subsection{Visuality through Background Noises}

Noise in radio documents - including the numerous background sounds one could hear in the coverage of protests during Mai 68 - could be understood as non-speech and non-music sounds. ${ }^{38}$ The various noise elements were powerful enough to suggest what was happening without any addition by the reporter, whether it concerned clashes between protesters and police forces or stampedes. Noises have a strong suggestive potential, and the noises present in the selected recordings were no exception. It is important to notice here the quality of the background sounds was still clear despite the variety of actions. This audio clarity was in part due to the technical characteristics of the Nagra recorder, praised by those who used it to cover the events at the time. ${ }^{39}$

In this regard, the fourth document was the richest in terms of violent background noises. Audio 4 starts with the sound of an explosion, and more explosions can be heard throughout the recording. It was likely that these sounds were made by the tear gas canisters, often used during the events of Mai 68. It was a sound that would have been known to French people at the time. The explosions were brutal and suggested violence; they were sounds of conflict, riot and war.

Other sounds, such as clashes and thuds, could be heard in the various documents, and they played a part in the shaping of an omnipresent violence in the scenes. As it was nearly impossible to determine the causes of those sounds, the impression of violence is reinforced by the feeling of the unknown associated with the sounds. The numerous sounds of footsteps heard at the end of the third document created the impression of masses, chaos, and movement. This impression was reinforced by the noise of people whistling and yelling, which could be heard on multiple occasions and submerged listeners in the action.

These short excerpts offered a glimpse of what was available on commercial radio stations during the events of Mai 68. They are particularly relevant to illustrate the richness of visual characteristics one could find in radio sources. This strong visuality appeared to be crucial in explaining the role played by $R T L$ and Europe $n^{\circ} 1$ and how they filled the vacuum in the French audiovisual media landscape due to the absence of television. Even though there were no live images, visual information was broadcast by commercial radio stations, pointing at the entanglements within the French audiovisual system.

\section{Conclusion}

As stated at the beginning of this article, the commercial radio stations $R T L$ and Europe $n^{\circ} 1$ were important witnesses and actors during Mai 68 , and the roles they played have to be understood through multiple elements. It is essential to look at the audiovisual media landscape, through the entanglements of television or radio, both public and private. It was only by taking a transmedial and transnational perspective, as both commercial radio stations targeted the French audience from beyond France's borders, that it was possible to understand how the crisis that affected the ORTF, partly triggered by the censorship applied to one television programme that affected all the various audiovisual media. The links between radio and television were strong as this case-study revealed, but they could lead to a better understanding of phenomena such as the vacuum created by the crisis affecting the French public broadcasting institution. This vacuum offered an interesting perspective into the 1968 events as it symbolized absence and silence, something essential to understanding the importance of what was heard and produced on peripheral radio stations. The commercial radio stations tried to inform their audience about the events as they were happening, which meant

38 Hugh Chignell, Key Concepts in Radio Studies, Sage, 2009, p. 91.

39 Interview between the author and Christian Brincourt, Paris, 10th March 2015. 
live radio was the quickest way to be informed during Mai 68, while the near-silence of the public service illustrated the tensions at stake in the ORTF.

It was when acknowledging this vacuum in the French public audiovisual media landscape that audio footage produced by RTL and Europe $n^{\circ} 1$ revealed particularly fascinating characteristics of the radio format. The liveness of the recordings, the omnipresent suggestions of violence and the emotions associated with the human voice characterized these audio documents that illustrated the events of Mai 68. They were also essential in explaining the central role radio stations played in the events, due to the informative and strongly visual characteristic of these recordings. These events also revealed the importance of information and news broadcast in French media, for both the audience and the radio reporters, as they were trying to fill in the gap left by television and public radio. Analysing how commercial radio stations behaved during this crisis indicates that they knew they belonged to an entangled media system as they actively tried to fill in the vacuum left by the silent public radio and television. Understanding the importance of commercial radio stations at the time was only possible by looking at the broader entanglements with other media, but also by looking at the very core of radio coverage, and this multi-scale analysis was a key to approaching the role of audiovisual media during May 1968 in France.

\section{Biography}

Richard Legay is a $\mathrm{PhD}$ candidate at the $\mathrm{C}^{2} \mathrm{DH}$, the Luxembourg Centre for Contemporary \& Digital History, where he conducts research on the history of commercial radio stations in Western Europe. His thesis is part of Popkult60, a research project (University of Luxembourg \& University of Saarland) on the transnational history of popular culture in the long 1960s. He holds a M.Phil in Public History \& Cultural Heritage from Trinity College Dublin and an MA in Contemporary European History from the University of Luxembourg. 